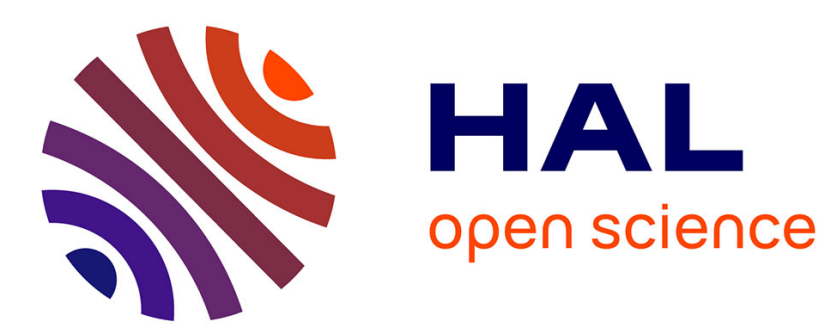

\title{
Restoring cultivated agrobiodiversity: The political ecology of knowledge networks between local peasant seed groups in France
}

\author{
Armelle Mazé, Aida Calabuig Domenech, Isabelle Goldringer
}

\section{To cite this version:}

Armelle Mazé, Aida Calabuig Domenech, Isabelle Goldringer. Restoring cultivated agrobiodiversity: The political ecology of knowledge networks between local peasant seed groups in France. Ecological Economics, 2021, 179, pp.106821. 10.1016/j.ecolecon.2020.106821 . hal-02979810

\section{HAL Id: hal-02979810 https://hal.inrae.fr/hal-02979810}

Submitted on 27 Oct 2020

HAL is a multi-disciplinary open access archive for the deposit and dissemination of scientific research documents, whether they are published or not. The documents may come from teaching and research institutions in France or abroad, or from public or private research centers.
L'archive ouverte pluridisciplinaire HAL, est destinée au dépôt et à la diffusion de documents scientifiques de niveau recherche, publiés ou non, émanant des établissements d'enseignement et de recherche français ou étrangers, des laboratoires publics ou privés. 


\title{
Restoring cultivated agrobiodiversity: The political ecology of knowledge networks between local peasant seed groups in France
}

\author{
Armelle Mazéa,*, Aida Calabuig Domenech ${ }^{\mathrm{a}}$, Isabelle Goldringer ${ }^{\mathrm{b}}$ \\ ${ }^{a}$ Université Paris Saclay, INRAE, AgroParisTech, UMR SADAPT, 75005 Paris, France \\ ${ }^{\mathrm{b}}$ Université Paris Saclay, INRAE, CNRS, AgroParisTech, GQE - Le Moulon, 91190 Gif-sur-Yvette, France
}

\section{A R T I C L E I N F O}

\section{Keywords:}

IAD/SESF

Social-ecological fit theory

Institutional economics

Peer-to-peer production

Participatory breeding

Community-based conservation

Seed Commons

\begin{abstract}
A B S T R A C T
This article, using an institutional and political ecological perspective, analyses the role of knowledge networks supporting peasant seed groups in France. These groups promote a dynamic approach to agrobiodiversity restoration, developing new models of collaborative "peer-to-peer genetics" and distributed participatory breeding. Our analysis focuses here on the small grain cereal participatory breeding group. Based on detailed qualitative surveys and a network formalization, our study provides a better understanding of how these peasant seed groups self-organized and of how their horizontal and distributed network structure favors the dynamics of collective learning and knowledge spillovers. Further directions for policy making are discussed in support of more resilient plant breeding and agrobiodiversity restoration in European agricultural landscapes.
\end{abstract}

\section{Introduction}

Agrobiodiversity conservation is a major challenge in the European context, where there has been a massive loss of collective knowledge about landraces and ancient varieties after several decades of agricultural modernization (Brac de la Perrière, 2014; Velten et al., 2018; Zimmerer and Haan, 2019). Among European countries, France is said to be one of the countries with a larger loss of cultivated agrobiodiversity, especially for main crops such as small grain cereals (Bonnin et al., 2014). Recent studies have also stressed the decline in climate resilience of European wheat as a result of the priority given to cropyield-related tipping points, the main drivers of agricultural modernization (Kahiluoto et al., 2019). Over the past few years, a number of peasant seed initiatives have played a key role in France raising awareness about the benefits of restoring cultivated agrobiodiversity and promoting the reintroduction of landraces and ancient varieties, as well as their on-farm conservation (Demeulenaere, 2014, 2018). ${ }^{1}$ However, restrictive seed laws and persistent misconceptions impose severe restrictions to their integration into policy promoting farm agrobiodiversity restoration and conservation (Pascual et al., 2011; Coomes et al., 2015; Velten et al., 2018; Gevers et al., 2019). Until now, valuable lessons from these studies have not reach the mainstream debates and policy making on the future of agriculture in the European context.

This article intends to contribute to these debates by exploring the specific features characterizing the knowledge networks that support a French peasant seed network, the Réseau Semences Paysannes (hereafter RSP), and especially its 'participatory wheat breeding group' (PWBG). Our analysis is based on the recent advances in the IAD/SESF ${ }^{2}$ literature on polycentric and networked forms of collective action (Ostrom, 2009; Ostrom and Cox, 2010; Epstein et al., 2015). In the IAD/ SES literature, the importance of network governance has increased considerably over recent years (Janssen et al., 2006; Newig et al., 2010; Bodin and Prell, 2011). Sustainability studies have highlighted the role of interindividual and social networks in facilitating information and knowledge-sharing among resource users (Ostrom and Cox, 2010; Bodin and Prell, 2011). However, recent advances in network research have also suggested that social and knowledge networks are not isomorphic, the latter meriting specific investigations (Glückler et al., 2017).

Our contribution is twofold. First, we provide a detailed original qualitative dataset and formalization of knowledge networks

\footnotetext{
* Corresponding author.

E-mail address: armelle.maze@inrae.fr (A. Mazé).

${ }^{1}$ In this article, we use the terms "peasant" and "peasant seeds" because they reflect the ontologies used and reclaimed by the actors themselves as distinctive

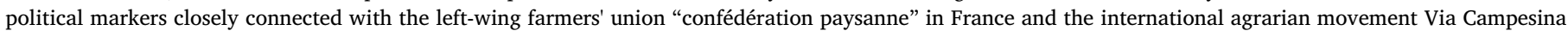

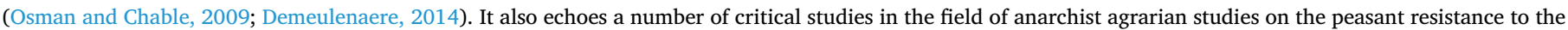

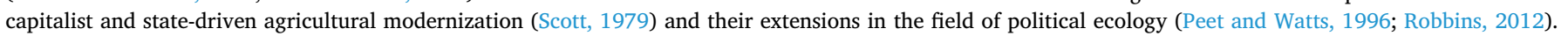

${ }^{2}$ IAD/SES: Institutional Analysis and Development/ Social-Ecological Systems.
} 
supporting the PWBG, which supplements previous studies on the political ecology of seed commons (Demeulenaere, 2014, 2018; Demeulenaere et al., 2017; Mazé et al., 2020). Second, our analysis suggests important insights about the models of collective action and the functioning of peasant-led community-based breeding adopted by the PWBG to support on-farm agrobiodiversity restoration. In the face of a blatant lack of research towards more resilient and hardy seed varieties, the PWBG also developed innovative strategies, including experiments and research activities, proposing a different route to innovation defined by Bonneuil and Demeulenaere (2007) as new models of "peer-to-peer genetics" and community-based breeding that are blending more effectively the experiential and situated knowledge of peasants with the most recent advances in population genetics (Dawson et al., 2011; Goldringer et al., 2012; Rivière et al., 2013).

This article is organized as follows. After providing a short overview of the legal context and the organizational innovations introduced by PWBG in section 2, section 3 develops the IAD/SES analytical framework with knowledge networks. Section 4 details the methodology and data set used to characterize peasant seed and knowledge activities. Section 5 presents our findings about the horizontal and distributed structure of knowledge networks involved in the PWBG and their role in knowledge accumulation and collective learning. Section 6 discusses remaining challenges and some policy implications to build more resilient collaborative peasant breeding and agrobiodiversity restoration in European agricultural landscapes.

\section{Agrobiodiversity restoration in European agricultural landscapes}

The rise of peasant seed networks in European countries marks a possible fundamental transformation in the governance of breeding and seed activities towards a more decentralized and pluralistic governing process of natural and environmental resources (Chable et al., 2020).

\subsection{The political rise of peasant seed networks in France}

In the face of an increasingly concentrated seed industry by large national and international companies, the emergence of peasant seed groups in France was first motivated by the threats posed by the dissemination of $\mathrm{GMOs}^{3}$ through supposedly GMO-free certified seeds; these groups took the initiative to better secure their own seed sourcing and to reassert their autonomy and independence from the seed industry (Bonneuil and Demeulenaere, 2007). Set up as a political and protest movement against restrictive national and European seed laws, they defend the peasant rights to breed and exchange seeds, preventing them from being patented, genetically modified, owned or controlled by small or large seed companies. The RSP actively defends peasant seed rights through the activist movement "liberate our seeds" (Demeulenaere, 2014; Demeulenaere, 2018; Girard and Frison, 2018).

In France, the RSP was formally created in 2003 as a grassroots association (under the so-called French Law of 1901) in southwest France, forming an inter-organizational web of more than 90 local collective groups situated in all main French regions, 12 of them being involved with the PWBG. The political project pursued by the RSP aimed to give a sense of resistance and self-empowerment of peasants against the hegemonic techno-scientific genetic discourses (Demeulenaere, 2014). ${ }^{4}$ The RSP rapidly started to promote the reintroduction of more diversified landraces and ancient varieties (Osman and Chable, 2009; Brac de la Perrière, 2014). Facing a blatant lack of research by the conventional

\footnotetext{
${ }^{3}$ GMOs: genetically modified organisms.

${ }^{4}$ A key step was that the RSP members reclaimed access rights to the ancient landrace varieties retained by the National Seed Collection managed by the public research institute INRA in Clermont-Ferrand, in charge of the ex situ conservation of small grain cereals in France (Demeulenaere, 2014).
}

seed industry on developing more resilient and hardy seed varieties, the RSP also found additional yardsticks for developing further experimental and research activities using landraces and ancient varieties (Goldringer et al., 2012; Demeulenaere et al., 2017).

\subsection{Recreating a shared collective knowledge about landraces and ancient varieties}

In European countries, agricultural modernization has deeply transformed local peasant communities. Oftentimes, there is no remaining individual knowledge of landraces or ancient varieties, nor of their specific seed attributes and adaptive responses to their soil-climate environments. Recreating rapidly a shared collective knowledge about landraces and ancient varieties was a priority (Brac de la Perrière, 2014; Lewrouw et al., 2014). However, as stressed by Berkes et al. (2000), the rediscovery of local ecological knowledge (LEK) has not been mired in the past but remains an evolving and creative knowledge-practice-belief complex. Inspired by other experiments conducted in Syria (Ceccarelli and Grando, 2007), a small group of cereal producers within the RSP started, with the methodological and technical assistance of a research team of population geneticists, a farmer-led participatory breeding for small grain cereals (Dawson et al., 2011; Goldringer et al., 2012; Rivière et al., 2013). These peasants also started to reclaim their status as "peasant-researchers" (Demeulenaere, 2014). Traditionally, farmers have always practiced what is called a "massal selection" based on observing the phenotypic traits of their plant populations, as well as their adaptation to their local terroir and specific soil-climate environment. Through their-day-to-day activities, accumulation of situated observations, continuous testing and experimentation, peasants are developing new knowledge and innovating (Demeulenaere et al., 2017).

Since its inception, the PWBG self-organized in a way to favor a collaborative approach between peasants and researchers; in which scientists, in this case, population geneticists, positioned themselves on an equal footing with the peasants, letting them express the diversity of their breeding preferences depending of their specific needs, farming practices and local soil and climate environment (Goldringer et al., 2012; Rivière et al., 2013). The PWBG has also innovated by developing new peasant population varieties that are better suited to the peasants' needs and their specific agro-ecological environment. By blending more effectively peasants' experiential knowledge with scientific knowledge in population genetics, the PWBG has thus given peasants the opportunity to further their knowledge about landraces and ancient varieties (Demeulenaere, 2014). It also suggests a possible paradigm shift from the dominant trait-based breeding adopted by the seed industry as population (peasant) varieties are looking for a better social-ecological fit (alignment), as defined by Epstein et al. (2015), with the spatial and temporal heterogeneity of the local environment and promoting a better co-adaptation and dynamic population conservation.

\subsection{Towards innovative models of peer-to-peer community-based breeding}

A major organizational innovation introduced by the PWBG is its efforts towards more collaborative, open, distributed and contextualized ways of organizing dynamic on-farm agrobiodiversity conservation. A growing number of studies consider these alternative peasant seed initiatives as "seed commons", e.g. collectively managed shared collective resources by local place-based peasant groups shaped by common values, knowledge ecosystems and rules of sociability (Demeulenaere, 2014; Mazé et al., 2020). Through its distributed and networked model of community-based breeding, the PWBG is thus proposing a break with the current corporate and entrepreneurial models adopted by the seed industry and their vertical labor division between peasants and breeders (Bonneuil and Thomas, 2009). Fig. 1 illustrates the differences between the current organizational model of the seed industry (left side) and the networked and distributed model adopted by the PWBG (right side). 


\section{Hierarchical and delegative organizational model adopted by the seed industry}

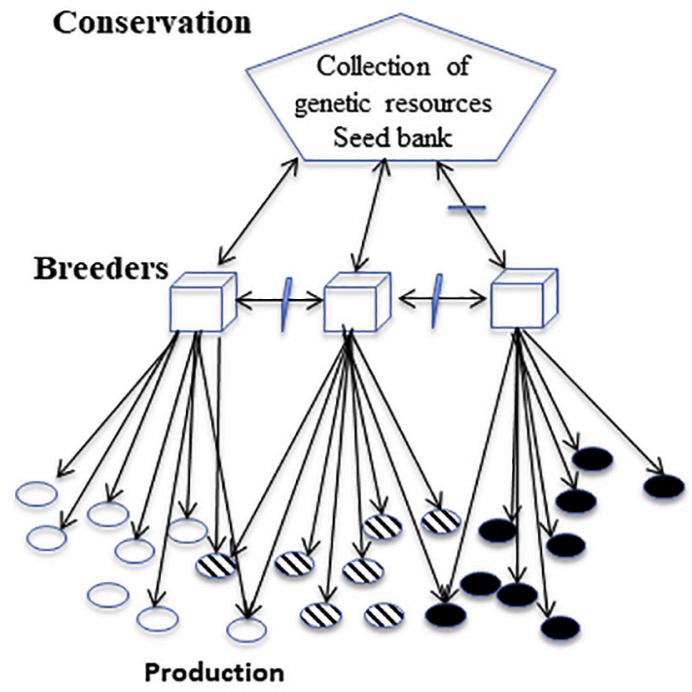

\section{Distributed and networked form of decentralized seed conservation, breeding and production by the french RSP}

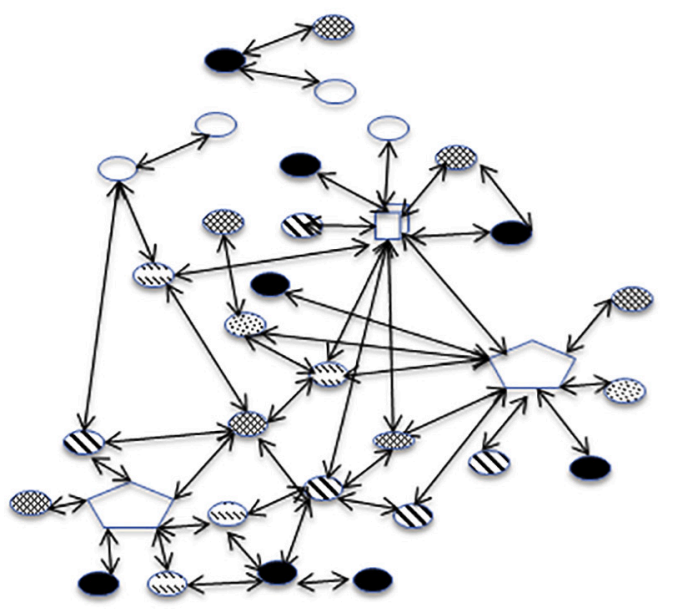

Deasants with different varieties ( $\neq$ shading)

Breeders

Seed collections, PSH, seed banks

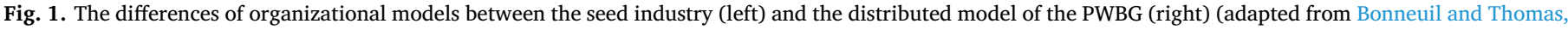
2009).

As part of their models of collective action, the strong ethical values conveyed within the PWBG about peasant's self-empowerment, equity, reciprocity and trust were mirrored by the distributed and horizontal network structure, and democratic decision making they adopted (Dawson et al., 2011; Demeulenaere, 2014; Mazé et al., 2020). Within the RSP, the peasants are no longer considered just as users of breeding innovations designed by others: now, they are themselves the actors and the innovators involved in a peer-to-peer process of knowledge, cocreation and open innovation, as defined by Von Hippel (2005). By giving more autonomy to peasants to develop their own rules, the network governance adopted by the PWBG aimed enhancing the reflexive individual and collective learning needed in the context of knowledge restoration (Demeulenaere et al., 2017; Mazé et al., 2020). A better understanding of the specific conditions under which these innovative peasant seed networks operate is still needed.

\section{Analytical framework}

To substantiate our analysis, we build upon the IAD/SES framework developed by Elinor Ostrom (2009) and recent analytical advances on the role of knowledge and collective learning in polycentric and networked forms of governance of SES (Janssen et al., 2006; Andersson and Ostrom, 2008; Newig et al., 2010; Bodin and Prell, 2011). ${ }^{5}$

\subsection{Knowledge ecosystems, collective action and self-governance}

In the sustainability literature, a growing body of studies has suggested that because polycentric and networked forms of governance enable actors to develop their own rules and organizations at multiple

\footnotetext{
${ }^{5}$ In the IAD/SES classificatory system (Ostrom, 2009), the network structure is represented by the variable GS3 and knowledge of SES by the variable U7. Evaluative criteria includes: i) economic efficiency and coordination costs; ii) fiscal equivalence; ii) redistributional equity; iii) accountability; iv) conformance to values of local actors; and v) sustainability over the long term (Ostrom, 2011).
}

levels, they also possibly work more effectively and achieve better suited social-ecological fit in solving local environmental issues due to lower coordination costs and facilitated knowledge transmission and monitoring strategies (Ostrom and Cox, 2010; Bodin and Prell, 2011; Epstein et al., 2015). Here, individual and collective learning are clearly conceived as a collective action problem themselves, which involves sharing experiences and engaging in collaborative governance. In their study, Ostrom and Cox (2010) suggested that such network governance can under some conditions outperform the classic top-down and hierarchical governance models, but possibly at the expense of higher coordination costs. Special attention must thus be paid to the balance between these different dimensions (Ostrom, 2009, 2011; Pahl-Wostl, 2009).

Over the past few years, network analysis offered a fruitful framework for theorizing and empirically investigating important socialecological interactions in the context of complex social-ecological systems (Ostrom, 2009; Bodin and Prell, 2011). Several studies considered the role of informal social networks between individuals as primary channels for knowledge flows on the co-management of natural resources. While informal networks play a crucial role in transferring and sharing knowledge, Folke et al. (2005) also suggested that "bridging organizations", such as the PWBG, may help lower the costs of collaboration, reduce behavioral uncertainty and favor mutual collective learning processes. A major challenge is thus, as stressed by Hess and Ostrom (2007), to blend more effectively systems of rules and norms, to deal with the knowledge gaps and to guarantee general access to knowledge while ensuring recognition and support for those who create knowledge in its various forms. A better understanding of the way knowledge ecosystems, collective action and self-governance function is needed.

\subsection{Collective learning and the selective nature of knowledge networks}

Due to the loss of traditional knowledge about landrace and ancient varieties, recreating a shared collective knowledge and social memory about cultivated agrobiodiversity couldn't be based on maintained 
traditional knowledge anymore. Furthermore, it requires special effort to recreate a shared, common and collective knowledge (Brac de la Perrière, 2014). A fundamental approach of the PWBG has been to recreate a collective space of knowledge exchanges and practices to harness both individual and collective learning through the day-to-day practice of seed handling and experimentation (Brac de la Perrière, 2014; Demeulenaere, 2014; Mazé et al., 2020).

In the innovation literature, many studies have also observed that knowledge diffusion operates in a selective and uneven way, suggesting the influence of structural properties of knowledge networks (Giuliani, 2007; Glückler et al., 2017). ${ }^{6}$ The structures of knowledge networks reflect the different internal capabilities to transfer and absorb knowledge at the local level and the heterogeneity of "knowledge bases" of network members, defined by their specific skills, know-how and knowledge domains. Hence, the collective groups with stronger "knowledge bases", which enhance their absorptive capacity, are more likely to be more central in the knowledge networks (Giuliani, 2007). If knowledge is not randomly distributed and follows structured patterns of knowledge diffusion and generation, a small subset of actors may actively participate in knowledge creation and absorption patterns. Stronger relational density can reflect stronger cohesiveness through knowledge exchanges, trust and social proximity. If some members value isolated strategies or outside partnerships more, weaker cohesiveness will be observed (Giuliani, 2007). We thus can assume that the heterogeneity of knowledge bases among the PWBG, and the complementarities of their know-how and fields of expertise, influences the structure of knowledge networks and the dynamics of collective learning and their innovative capacities.

\subsection{Network cohesion, modularity and dynamics of spatial clustering}

The analysis of network topology is thus useful to better understand the formation and evolution of network dynamics and their determinants (Glückler et al., 2017). In the IAD/SES literature, the network structure has been primarily characterized by variables such as centrality, modularity and connectivity (Bodin and Prell, 2011; Cox, 2014). The modularity of the network structure is characterized by the existence of subgroups with denser links between their individual members. A modular conformation of networks takes advantage of the geographical proximity and the local embeddedness in their environment, facilitating collective problem solving and reducing transaction costs (Cox, 2014). In knowledge networks, nodes are viewed as repositories of knowledge. Due to the power of spatial clustering and localized knowledge spillovers for learning and increasing innovative capacity, clustered groups often show a higher innovative capacity than isolated actors (Giuliani, 2007; Glückler et al., 2017).

If geographical proximity and the embeddedness of the actors in local networks positively affect learning and innovative processes, the diffusion and generation of knowledge is likely to be differentiated depending on existing asymmetries and the heterogeneity of the actors' knowledge base (Giuliani, 2007). Network segregation also indicates that there are incentives for actors to occupy strategic positions between fragmented communities. The centrality of an organization's position is influenced by its size, its absorptive capacities, or the openness of its organizational model (Giuliani, 2007). Networks are also subject to possible trade-offs and tensions between triadic closure and openness, which can affect the knowledge spillovers, spatial dynamics and network sustainability. In the next sections, we analyze more precisely the structure of knowledge networks supporting the PWBG and their role in the dynamics of knowledge accumulation and

\footnotetext{
${ }^{6}$ In classic social network analysis, centrality of some actors is defined by "high ranking nodes that have a significantly higher than average social capital, leadership or mutual trust, and thus, a higher number of links and/or links stretching beyond their local network neighborhood.
}

dissemination.

\section{Methodology and data}

Our field study focuses on the RSP's cereals group and its Participatory Wheat Breeding Group (PWBG), forming a web of 14 local peasant seed groups (and a few isolated individuals) located in different regional areas in France (Fig. 2). ${ }^{7}$ By covering noncontinuous territories the PWBG is operating as an open and horizontally distributed network connecting independent local peasant seed groups in different regions with a large range of soil-climate environments: from the Atlantic coast, the Parisian Basin and northern France/Belgium to the mountainous Massif Central and the Alps, and the southwest and Mediterranean areas.

\subsection{Methodology}

To analyze the knowledge networks supporting the PWBG and their role in the dynamics of knowledge co-creation and collective learning, we have adapted and extended the methodology developed by Giuliani (2007). In her study, the importance of "knowledge base" is defined by R\&D investments and qualified personnel, the levels of education and training, and the nature and intensity of experimentation (Giuliani, 2007). In the case of the PWBG, the seed group's activities are not restricted to seed exchanges but also involve a diversity of other seed activities, such as prospection, conservation, and population breeding. Our interviews showed that two dimensions were particularly important for the local seed groups in developing their own "knowledge base" on landraces.

- The diversity of seed activities and the degree of day-to-day involvement, training and experimentation in seed handling are central in fostering knowledge accumulation about the adaptive comanagement of landraces and ancient varieties and new peasant breeds with their local climate/soil environment. The more diversified seed activities they have, the more opportunities they have for knowledge co-creation and capability building.

- The level of participation in the PWBG is a key aspect to foster knowledge accumulation and reflexive learning. Thus, the more involvement there is in the participatory breeding activities, the more opportunities for individual and collective learning and knowledge co-creation, leading to a more central position in the network.

Our methodology involved the following steps. Conceptually, we first started by characterizing the different seed activities performed by the different groups, differentiating seed prospection, ex situ and in situ conservation, selection, multiplication, dissemination, and their role in knowledge accumulation and dissemination. In the second step, we identified the links connecting the network members with each other and with their local research environment. Thus, the intensity and quality of knowledge co-creation and exchanges were assessed through different proxies defined in Table 1, such as their degree of involvement in the PWBG and their participation in training, workshops, seminars or other activities such as farm visits, technical support, meetings, research projects, experiments or breeding activities. Table 1 summarizes the scale and criteria to assess their involvement in the PWBG activities.

\subsection{Data collection}

Our study combines qualitative data on the historical development of the PWBG, the characteristics of member groups and individuals,

\footnotetext{
${ }^{7}$ Annex 1 presents all the local peasant seed groups participating in the PWBG, their acronyms in figures and their main characteristics.
} 


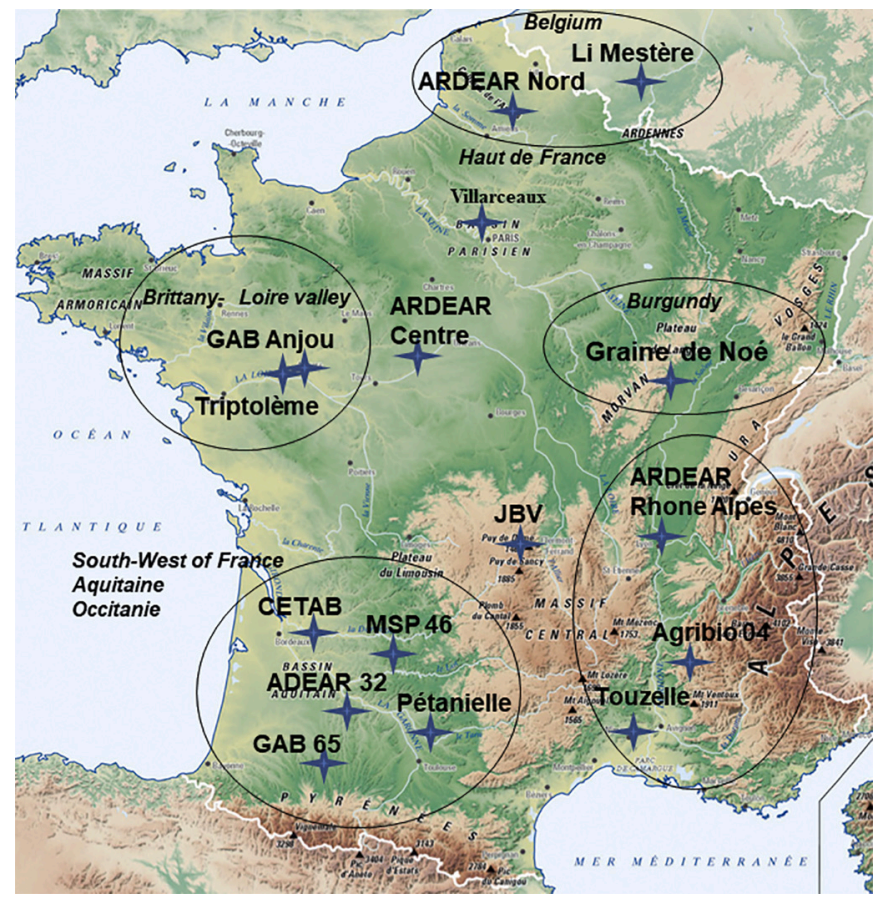

Fig. 2. Localization of the local peasant seed groups of the PWBG.

Table 1

The scale and criteria used to establish these relationships are as follows:

0 - No specific relationship between association members

1 - Participation in the same project: Programme Leonardo, GROW, RSP meetings,

2 - Exchange of information and data through different projects: Routine selection projects, database, national meetings, $\mathrm{PhD}$ thesis (first projects) 3 - Exchange of information and knowledge: National (Renabio, semaine SP) and international meetings (Belgium 2017, Let's liberate diversity), SOLIBAM meetings, relations with research (ITAB, INRA-results of projects) 4 - Exchange of knowledge (between associations): Speeches, training (baking), workshops, farm visits, technical support, counseling, SOLIBAM evaluation (structuring of projects, exchange of knowledge and results, meetings); seed exchanges/distribution without a close relationship, such as C32, CTB, AD N, Trp 5 - Project ECOAGRI (which helped structure the group): Exchange of seeds, knowledge and experiences; meetings; relationship reinforcement between participants

6 - Close relation-partnership: Exchanging seeds; working together frequently; sharing seed samples, varieties, mixtures; seed collection; working together on local projects

their different seed activities, their degree of involvement and the interactions with researchers through specific regional, national or European research projects. The survey was carried out between March and June 2017 through twenty semi-structured interviews with representatives (facilitator or key peasant) of all the groups involved in the PWBG and researchers. Secondary data were collected from internet websites and internal documentation on research projects and other activities (open days, training). Last, a triangulation of data was carried out through a "roster recall" method about the nature and intensity of interactions and involvement of each local group or individual with the PWBG.

\subsection{Network nodes and links}

The network formalization follows classic procedures in network analysis, including the identification of the structural configurations and network characteristics (nodes, links and attributes). We also elaborated specific metrics and criteria to characterize the nature and intensity of the relationships between the local peasant's seed groups involved in the PWBG. ${ }^{8}$ Each network node represents a specific collective peasant seed group/individual and an oriented tie from one association (i) to another ( $\mathrm{j}$ ), indicating that the collective group has been exchanging information and knowledge about its seed collections, experiments, and research activities. Each collective group member of the PWBG was also characterized by the following attributes defining its "knowledge base":

i) the size of their collection, including the number and type of varieties,

ii) the nature of breeding and experimentation platforms,

iii) their seniority in the network in relation to the year of joining PWBG (Annex 1),

iv) their degree of specialization related to the type of seed activities or plant species,

v) the degree of involvement in the PWBG and related seed activities, and

vi) their participation in EU funded or national research projects.

\section{Results and analysis}

In the next sections, we present the main findings characterizing the influence of the knowledge base of local peasant seed groups on the network structure (5.1), the nature and intensity of knowledge exchanges within the PWBG activities (5.2), the differentiated involvements of the local groups in the PWBG (5.3), the specific local knowledge ecosystems they created (5.4), and the dynamics of the network (5.5).

\subsection{The influence of the knowledge base on the network structure}

An important outcome of the network analysis was to highlight the specific preferences of each local group in developing their own seed activities and how it influences their specific knowledge accumulation about landrace and ancient varieties. During our interviews, several groups mentioned that the management of the breeding and propagation platforms requires much time and effort, which is proportional to the number of varieties cultivated each year. The capacity of the collective groups to manage such a large number of varieties within a collection of 200-300 varieties is a key dimension characterizing the primary groups in the network (ARDEAR Rhone Alpes (AD R-A), Triptolème (Trp), CETAB (CTB), Graine de Noé (GdN), Limestère (LM)) and their respective experience with and knowledge about how to do this, defining their respective knowledge capital in handling seed activities.

Fig. 3 provides an overview of the interactions within the network and shows the groups with the strongest knowledge base by the experience that they accumulated through day-to-day manipulation of and experimentation with ancient and landrace varieties. Each group is represented by three elements: i) the size of the seed collection and the number of varieties conserved (up to 300 varieties); ii) their degree of involvement in the PWBG; and iii) the types of varieties that they are interested in, e.g., only ancient landrace varieties conservation (purple color), newly designed peasant varieties as an outcome of the PWBG (blue color) or a mix of the two ancient landrace varieties conservation and newly designed participatory peasant variety developed by the PWBG (black color).

In Fig. 3, the group of Graine de Noé (GdN) occupies a central position (node with a purple square) in comparison to the others, which is linked to its seniority in terms of working with landrace seed varieties, the size of its collection and its key role in the on-farm conservation of

\footnotetext{
${ }^{8}$ The network formalization was completed using the software program UCINET (version 6.631)
} 


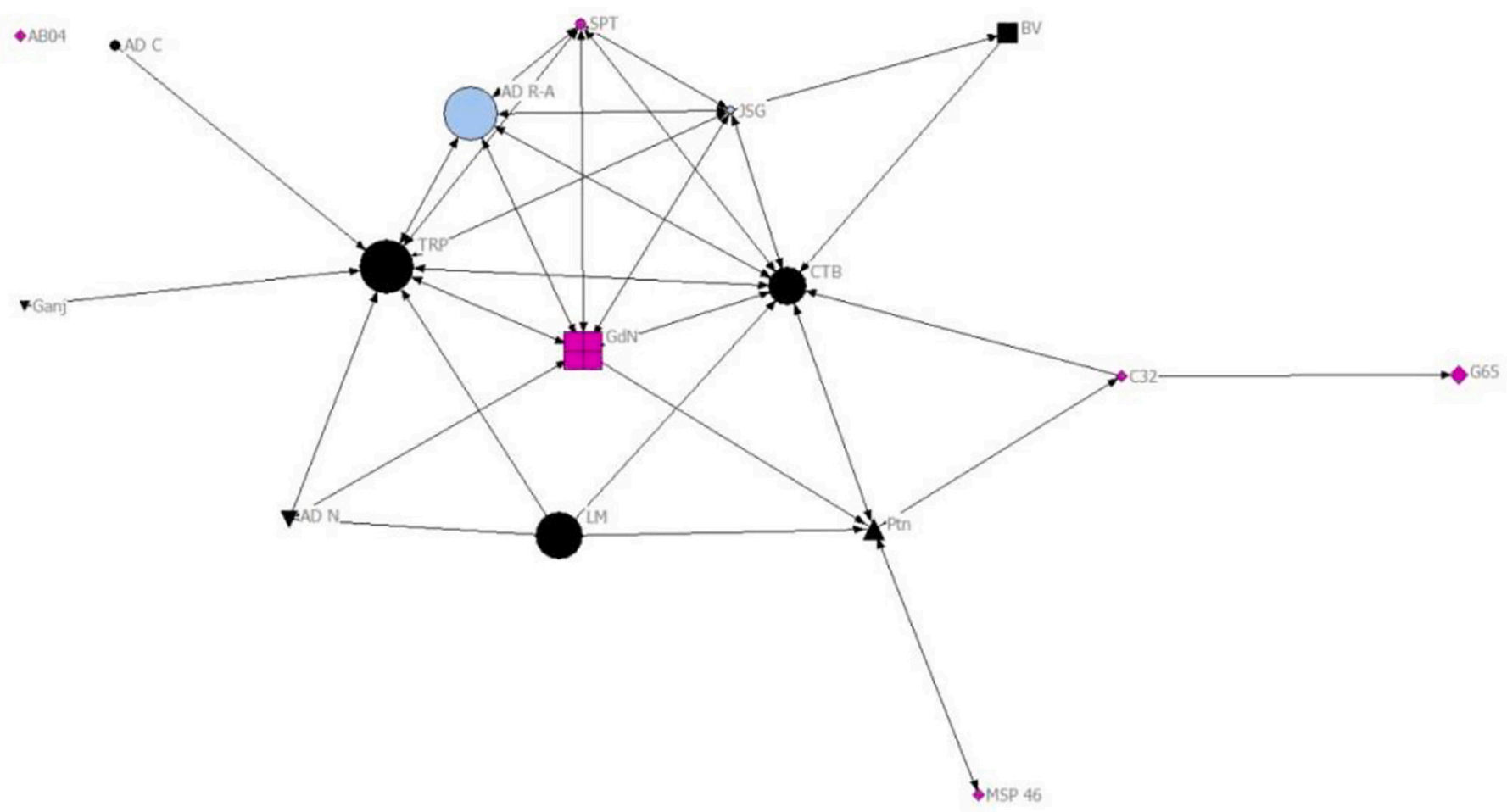

Fig. 3. The PWBG knowledge network and its primary groups (scale 4 to 6 ).

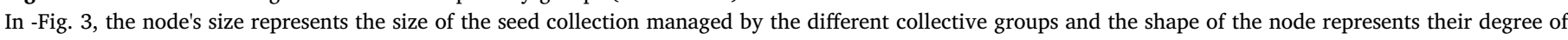

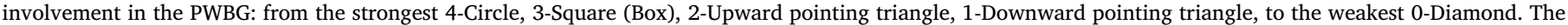
colors represent the different focus in seed activities: conservation (purple), new breeding activities (blue), or both (black).

seed collections. In contrast to the other core groups, GdN is less involved in new breeding activities, prioritizing seed conservation and knowledge dissemination about landraces and ancient varieties. The other primary groups CETAB (CTB), ARDEAR Rhone Alpes (AD RA), and Triptolème (Trp) (see Fig. 3) have more diversified seed activities in relation to ancient and landrace seed varieties, also giving more space to innovative breeding strategies. Knowledge exchanges seem to be more important (scale 4 to 6) among these primary groups, as represented in Fig. 3, that also have the most important seed collections. Thus representing a good indicator of their knowledge base about landraces and ancient varieties in relation to the diversity of seed activities that they are conducting.

Each primary group can thus be considered a "knowledge leader" in a specific field due to the know-how acquired in different domains, such as the conservation of ancient and landrace varieties (GdN), the dynamic management of crop populations and seed mixtures (Trp) or cross-breeding and bread-making (CETAB). By developing complementary, but still overlapping, domains of know-how and expertise, the different groups fostered peasant interests, knowledge dissemination and training within the network. The other less central groups in the network dynamics (MSP MSP46, G65, AB04, C32, etc.) appear to play the role of "knowledge takers", as they prioritize specific valueoriented models (bread-making with landraces, eco-tourism, etc.), with a lower investment in the core collective activities of the PWBG, while still participating in information dissemination.

\subsection{Knowledge cocreation and exchanges: differentiated positions}

The nature and intensity of knowledge exchanges defined the horizontal links between the groups that were more involved in the network (only scales 5 and 6) in comparison to the overall interactions (scales 1 to 6). Fig. 4 highlights the differentiated position of each group in relation to its respective knowledge base and specific domain of expertise about ancient and landrace seed varieties. Fig. 4a shows the groups with the strongest relationships (scales 5 to 6 ), compared to Fig. 4b representing all the interactions, including the weakest (scales 1 to 6). The primary groups identified in Fig. 3 ( $\mathrm{GdN}, \mathrm{AD}$ R-A, Trp, CETAB) with the largest size of seed collections and stronger internal capabilities and knowledge base about ancient and landraces varieties are also more central in Fig. 4a and Fig. 4b.

The more peripheral groups, as illustrated in Fig. 4b, are on the right side: these are the collective groups that are more interested in a valueoriented model (specialty bread, branding strategies, etc.), such as the AB04, G65, and MSP 46 groups that work more independently ${ }^{9}$. On the left side are the few individuals (BV, JSG, SPT) involved in conservation and breeding activities but who interact less with the rest of groups due to personal time constraints. Even if less central, both subgroups contribute to the PWBG activities through data collection, breeding and conservation activities, as well as knowledge dissemination outside of the network. Weak ties still play an important role in information gathering and dissemination.

The dynamic and evolving nature of participation in network activities is also a key aspect. While early participation in the first research projects was ranked 2 or 3 (see Table 2 below), participation in more recent research projects was ranked 4 and 5 as the knowledge contribution of the groups was greater in the latter projects due to a stronger knowledge base and collective experience acquired by the participants. New PWBG members also appear to be more active in the collective network activities, indicating the importance of the initial learning process and knowledge acquisition before becoming more selfsufficient and autonomous in their own breeding activities and experiments. $^{10}$

\footnotetext{
${ }^{9}$ In Figure $4 b$, network density is higher on the right side, indicating stronger interactions between collective groups, as compared with individual members who interact less with the rest of the groups due to lack of time (situated to the left side).
} 


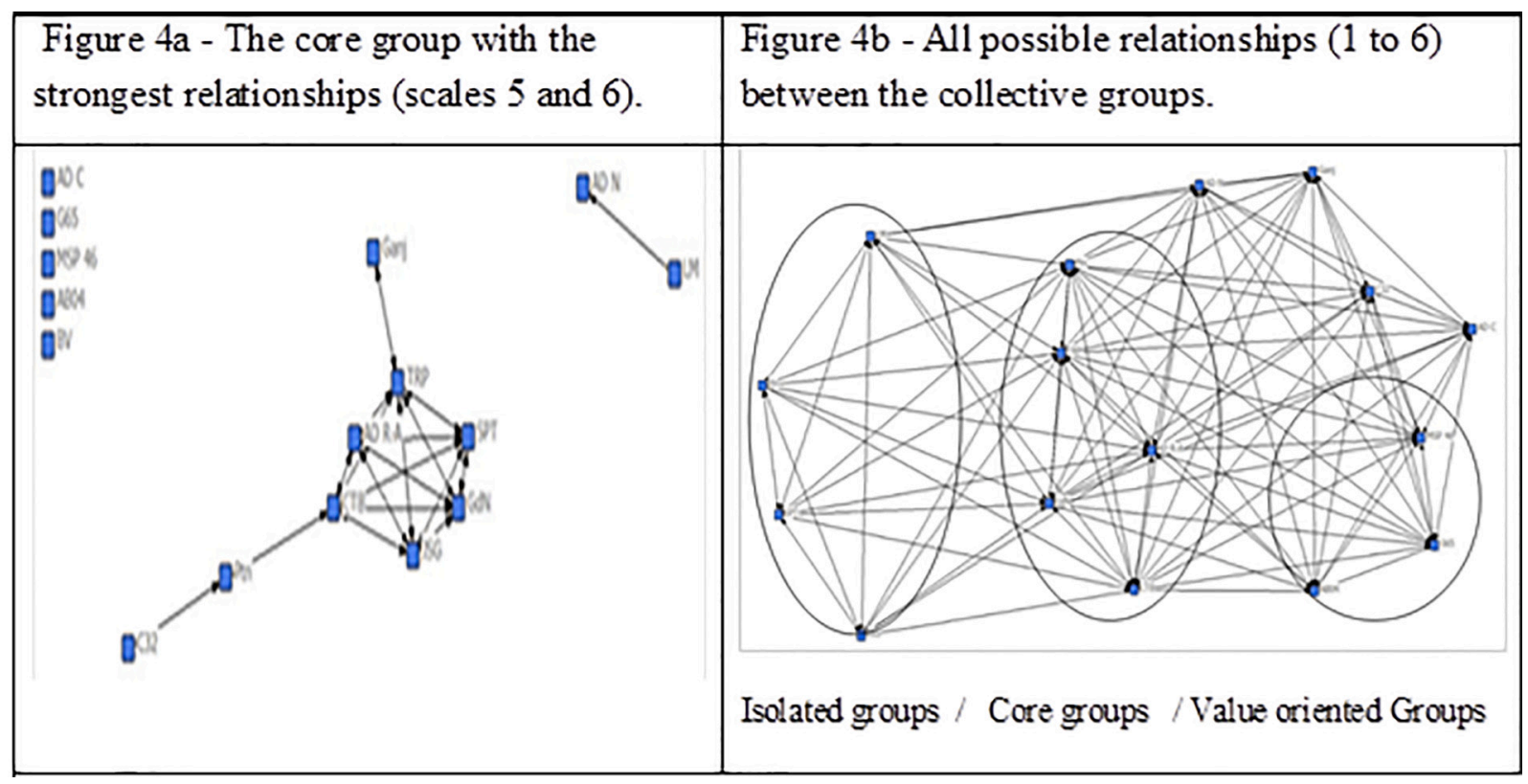

Fig. 4. The core collective groups within the PWBG.

\subsection{Differentiated involvements in the PWBG activities}

A major driver of the network's development was the involvement of the PWBG in formal research projects which influenced its progressive structuration over time. Research projects provided additional financial resources and fostered knowledge co-creation and dissemination among the groups. This was achieved through joint activities stimulating mutual aid and collaborative arrangements among the participants. A more precise analysis showed that, in fact, this participation varies across time and depends on the specific interests of each local peasant seed group, as reflected in Table 2 .

Table 2 also shows the differentiated positions between the primary groups and those more at the periphery within the collective dynamics. Whereas a primary group (scale 4) is strongly involved in all PWBG activities, with a specific interest in breeding, another group is more involved in seed conservation (scales 2 and 3). The last two groups show a lower level of involvement due to time constraints (scale 1) or their specific interest in specific landrace varieties and strategies of value creation (specialty bread, local brand names, etc.). Differences in knowledge bases and field expertise accumulated by the different groups also influence the nature of their involvement in the PWBG activities.

Considering this heterogeneity is important in terms of managing the network dynamics and the collective strategies for agrobiodiversity restoration. It reflects differences in learning trajectories and building capabilities: those that joined the group more recently and are more interested in breeding activities, have stronger needs in terms of knowledge acquisition and are thus the most involved. However, once a minimum knowledge base has been acquired, some groups have less interest in continuing, resulting in a lower participation in the PWBG and a potential reduction of knowledge spillovers among the participating groups. This questions the overall network dynamic and sustainability over time.

\footnotetext{
${ }^{10}$ The groups with small collections still play an important role in seed and knowledge dissemination. When joining the PWBG, it is observed that peasants often start experimenting and developing their own seed collection. Thus, such decentralization and dissemination increase the potential social-ecological fit and adaptability of population (peasant) varieties to different farming practices, and soil and climate conditions.
}

\subsection{The development of local knowledge ecosystems}

Whereas the RSP played a key coordination role, the ability of the local peasant seed groups to mobilize other resources and to develop their own knowledge ecosystems and new forms of collaborations with local research partners was also crucial (Fig. 5). The connections with the research team INRA Le Moulon (Isabelle Goldringer) specializing in population genetics were central in the progressive structuration, dayto-day coordination and facilitation of the PWBG and in providing the genetic technologies and related analytical and mathematical tools needed for the design of field experiment settings, as well as identifying and taking into account the specific peasants' organizational constraints (Dawson et al., 2011, Goldringer et al., 2012; Rivière 2014). ${ }^{11}$ This central position is clearly defined in Fig. 5 and highlights the modular structure of the PWBG and the connections between the peasant groups and local research partners (INRA centers, ITAB, agricultural engineering colleges).

Joint participation in research projects has created the conditions and space for knowledge exchanges and coproduction between researchers, facilitators and peasants. By functioning as a "knowledge platform", the PWBG generates positive knowledge spillovers towards its members located in different regions. Research was conceived to be supportive in different ways: i) in the search for varieties at public genetic resource centers, ii) as a source of scientific knowledge, and iii) in the organization of evaluation and selection trials (Goldringer et al., 2012; Rivière, 2014). While peasant seed groups are keen to reclaim their autonomy and independence from public research institutions, our study shows that they still benefit from local research support, which provided useful help to conduct experiments and trials (Rivière et al., 2013). This includes specific projects conducted with a technical institute on organic production (ITAB) ${ }^{12}$ and several local INRA research laboratories in Rennes (Brittany), Orléans (Central and Loire Vallée

\footnotetext{
${ }^{11}$ Added analytical tools developed by the research team include specific mathematical tools that help visualize and objectivize the genetic outcomes of the phenotypic breeding strategies and the so-called "massal selection" practiced by the peasants involved in the PWBG (Rivière et al., 2013).

${ }^{12}$ For example, ITAB carries out studies regarding the nutritional and organoleptic qualities of organic bread derived from peasant varieties and gives technical support on organic farming. Moreover, one of its experimental sites is located in one of the member groups in the network (BV).
} 
Table 2

The degree of involvement of collective groups in the PWBG.

\begin{tabular}{|c|c|c|}
\hline Degree of involvement & Characterization of the involvement degree & Groups \\
\hline 0 - weak & Weak relationship, very few contacts, no participation in meetings & AB04, MSP 46, C32, G65 \\
\hline 1 & $\begin{array}{l}\text { Involvement mainly through the coordinator or a few individuals participating in the meetings, but does not } \\
\text { conduct breeding activities with the PWBG }\end{array}$ & AD N, Ganj \\
\hline 2 - medium & Participating in landrace seed conservation and providing seeds but not in breeding activities & Ptn \\
\hline 3 & $\begin{array}{l}\text { Regular involvement (OR) but more interested in seed conservation, with weaker participation in a breeding } \\
\text { program (even if providing seeds) }\end{array}$ & GdN \\
\hline 4 - strong & $\begin{array}{l}\text { Regular involvement and active in selection activities, truly interested in selection and dynamic in situ } \\
\text { population breeding }\end{array}$ & $\begin{array}{l}\text { AD R-A, JSG, AD C, Trp-FM, LM, CTB, } \\
\text { JFB, SPT }\end{array}$ \\
\hline
\end{tabular}

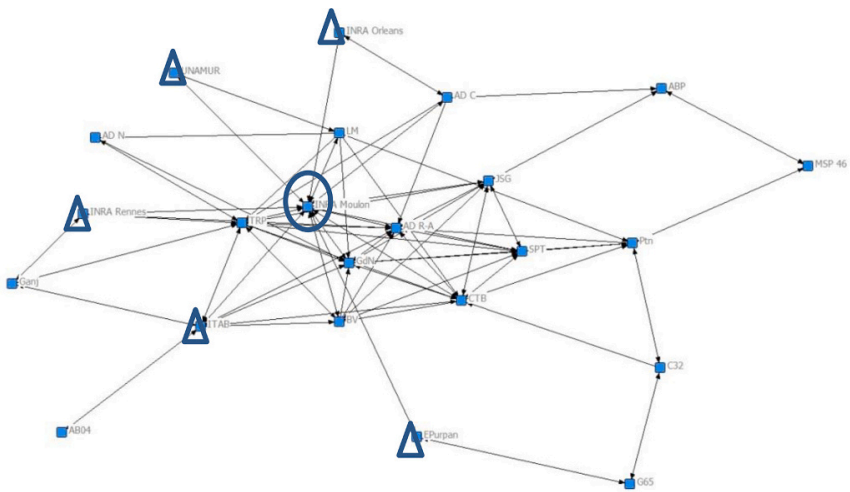

Fig. 5. The knowledge ecosystems surrounding the PWBG (values from 3 to 6) Legend: The circle represents the INRA Le Moulon and the triangle represents the local INRA centers, ITAB and agricultural engineering colleges.

regions) and agricultural colleges (such as in Purpan near Toulouse). They provided experimental platforms both for in situ conservation of seed collections and for plot experiments. Thus, rather than operating in isolation, one of the PWBG strengths is related to its capacity to develop new alliances and local knowledge ecosystems aligned with their specific needs and objectives (Mazé et al., 2020).

\subsection{Network modularity and the dynamics of local spatial clustering}

A key aspect of the PWBG is being able to connect collective groups that were not located in the same region around a shared activity, e.g., the development of collaborative breeding that facilitated knowledge exchange and empowered the peasants to develop their own breeding activities (Mazé et al., 2020). Characterized by territorial discontinuities, the modular network structure adopted by the PWBG has been positively enhancing knowledge spillovers between the different peasant seed groups, as well as strengthening their capabilities to maintain, over time and across places, dynamic seed collections covering hundreds of different varieties and thus ensuring their socialecological fit to various soil and climate environments. Over time, different spatial dynamics were nevertheless observed within the PWBG in relation to endogenous group dynamics and to the specific financial and political support they received from regional public authorities:

- In the southwest, covering the regions of Aquitaine and Occitanie, the connections with the local collective group AgroBio Périgord (ABP), another RSP member, developed a strong know-how, matured expertise in the maize breeding, and stimulated knowledge spillovers across species (maize, cereals, vegetable, perennials) among the groups.

- In Burgundy and Rhone-Alpes, the local groups were more motivated by the conservation of patrimonial heritage and faced a rapid demand increase for organic products,

- In the west of France (Brittany, Loire Vallée), strong connections with the research laboratory INRA Rennes (Véronique Chable), operating as an EU project leader, provided facilitated access to funding and created positive knowledge spillovers.

These local dynamics favored the formation of local clusters, giving more visibility to the promotion of peasant seeds and their dissemination. Geographical proximity facilitates knowledge spillovers through spatially close groups and embedded in local networks of informal contacts. Nonetheless, in regions where conventional agriculture is dominant or where peasants are isolated, the connection with the PWBG activities at the national level remains crucial.

\section{Discussion}

Our findings provide important information on how the PWBG and its local seed groups collectively self-organized and developed a set of innovative peasant seed activities. Whereas dynamic in situ conservation of landraces and ancient varieties is central, our analysis suggest that this is the combination of different seed activities, including collaborative breeding and joint research on new population varieties that stimulate both individual and collective learning dynamics. It has generated new sources of diversification for peasants looking for varieties better suited to their specific needs and value creation in the context of low input and organic systems. Our analysis of the knowledge networks supporting the PWBG shows the value of the horizontal and distributed network approach they adopted by linking separate networks segments and helping new members to develop their capabilities in handling landraces and ancient varieties. In the network literature, a bridging actor often assumes a broker position that favors the development of strong ties, producing higher private and social returns to its members. This network cohesion has thus a positive effect on knowledge sharing and co-creation among heterogeneous actors but also in connecting and generating positive knowledge spillovers in favor of isolated groups or individuals. It thus shows the importance of the network dynamism in terms of ensuring that new knowledge is available and in creating complementarities and synergies between different local peasant seed groups. The overall network dynamic is nevertheless also subject to the risks of classical trade-offs between network closure and openness.

A major remaining challenge for the PWBG and its local peasant seed groups is the lack of stable financial and human resources, and the local political instability which is affecting their access to financial support. ${ }^{13}$ To give more visibility to their seed activities, some members of the RSP launched the concept of "peasant seed houses" (PSH), inspired by Brazilian experiences of "casas de sementes criollas" (Lewrouw et al., 2014). This initiative facilitated their access to EU funding through the 2nd pillar of the Common Agricultural Policy (CAP) on territorial development. However, such EU funding is managed at the regional level creating disparities between the different

\footnotetext{
${ }^{13}$ For example, the change of political majority in the region Rhone-Alpes (South East) after the regional election in 2015, led to a drop in the public support provided to organic production and related advisory services, such as the ARDEAR Rhone-Alpes, a member of the PWBG.
} 
Annex 1

Main attributes of the local seed groups involved in the PWBG

\begin{tabular}{|c|c|c|c|c|c|c|c|}
\hline & Group's names (acronym) & Acronym & Region & $\begin{array}{l}\text { Year of initial PWBG mem- } \\
\text { bership }\end{array}$ & $\begin{array}{l}\mathrm{Nb} \text { individual } \\
\text { members }\end{array}$ & Specialisation & $\begin{array}{l}\text { Nb cereal varieties col- } \\
\text { lection }\end{array}$ \\
\hline 1 & ARDEAR Rhone Alpes & AD R-A & Rhone Alpes & 2004 & 40 farms SP & $\begin{array}{l}\text { Corn, cereals and forage } \\
\text { species }\end{array}$ & 300 \\
\hline 2 & Graine de Noé & GdN & Burgundy & 2009 & 150 & Cereals & 200 \\
\hline 3 & CETAB & СТВ & $\begin{array}{l}\text { Occitanie, South } \\
\text { west }\end{array}$ & 2005 & 50 & Cereals & 200 \\
\hline 4 & ARDEAR Centre & $\mathrm{AD} \mathrm{C}$ & Loire Vallée, Centre & 2012 & unknown & $\begin{array}{l}\text { Corn, cereals, sunflower, } \\
\text { forage s }\end{array}$ & - \\
\hline 5 & ARDEAR Nord & AD N & Northern France & 2012 & 50 & Cereals & 50 \\
\hline 6 & Pétanielle & Ptn & $\begin{array}{l}\text { Occitanie, } \\
\text { SouthWest }\end{array}$ & 2011 & 180 & Cereals & 90 \\
\hline 7 & Limestère & LM & Belgium & 2014 & 100 & Cereals & 250 \\
\hline 8 & GAB 65 & G65 & $\begin{array}{l}\text { Occitanie South } \\
\text { West }\end{array}$ & $2009 / 13$ & 21 & Cereals & 50 \\
\hline 9 & $\begin{array}{l}\text { Maison des Semences } \\
\text { Paysannes } 46\end{array}$ & MSP 46 & $\begin{array}{l}\text { Occitanie } \\
\text { SouthWest }\end{array}$ & 2014 & 40 & Corn, vegetables & 0 \\
\hline 10 & AgriBio 04 & АB04 & South East & $2003 / 2017$ & 5 peasants SP & SP: Wheat & 1 \\
\hline 11 & GAB Anjou & Ganj & Loire Vallée & 2004 & 15 & $\begin{array}{l}\text { Wheat, sunflower, corn, } \\
\text { vegies }\end{array}$ & see $\operatorname{Trp}$ \\
\hline 12 & ADEAR 32 & C32 & Occitanie & 2013 & 15 & Vegetables/cereals & 200 \\
\hline 13 & $\begin{array}{l}\text { Syndicat de promotion de } \\
\text { Touzelle }\end{array}$ & SPT & South East Provence & 2005 & 80 & Cereals & 13 \\
\hline 14 & Triptolème & Trp & Loive Vallée & 2006 & 80 & Cereals & 300 \\
\hline 15 & Individual peasant $\mathrm{BV}$ & BV & $\begin{array}{l}\text { Ile de France Paris' } \\
\text { area }\end{array}$ & 2003 & $1-10$ & Wheat & 80 \\
\hline 16 & Individual peasant JSG & JSG & Auvergne & 2007 & 1 & Cereals, corn, sunflower & $?$ \\
\hline
\end{tabular}

PWBG groups. It also prevented the RSP, coordinating the PWBG at the national level, to have access to these financial resources.

Favoring some regions, especially in the South-West where the peasant seed groups are currently forming an experienced cluster, creates incentives for these groups to invest less in the PWBG activities. Over time, this situation could negatively affect the other groups located in less favored regions where conventional agriculture is dominant and where the knowledge spillovers created by the PWBG are needed the most. Several studies have highlighted the current limitations of economic mechanisms supporting agrobiodiversity restoration, mainly through individual or collective agro-environmental incentive schemes (Pascual et al., 2011). Other policy toolboxes such as "community seed banks" (CSB) have remained out of the CAP instruments. Investing in such agro-ecological infrastructures, as CSB or PSH promoted by the RSP, was recently suggested by several European peasant seed initiatives and could be a substantial lever of action for policy changes (Koller et al., 2018). ${ }^{14}$

\section{Conclusion}

Our study provides several important insights to rethink dynamic on-farm agrobiodiversity governance in the European agricultural landscape, and overcome a number of misconceptions that have prevented the recognition and integration of peasant seed groups into European public policies (Mc Guire and Sperling, 2013; Coomes et al., 2015). Conflict and power struggles about seeds involve tremendous asymmetric forces and resistances. As suggested by Ostrom (1990, 2009), this is only because the seed commons are organized collectively that they can be a viable alternative to markets or state management. In the face of growing criticism towards the linear and top-down model of breeding innovation in agriculture, a number of studies called for a paradigmatic reorientation of plant breeding systems, giving more space to the coexistence with alternative community-based breeding (Bonneuil and Thomas, 2009; Vanloqueren and Baret, 2009). Challenging the dominant view of peasant-led collaborative breeding as a form

\footnotetext{
${ }^{14}$ See https://www.communityseedbanks.org/
}

of low-tech and frugal innovation requiring low investment, our findings show that the PWBG stimulated innovative forms of collective experimentation and research in the search for better suited population varieties for organic and low-input farming systems. Acknowledging and financially supporting these farmer-led collaborative breeding as part of local agro-ecological infrastructures could be an important step towards agrobiodiversity restoration in European agricultural landscapes.

\section{Declaration of Competing Interest}

The authors declare that they have no known competing financial interests or personal relationships that could have appeared to influence the work reported in this paper.

\section{Acknowledgements}

This work was part of the research project "SENAC" (SocialEcological Networks in A Changing world) supported by a grant overseen by the French National Research Agency (ANR) as part of the "Investments d'Avenir" Programme LabEx BASC (ANR-11-LABX-0034). Additional funding was provided by the INRAE through its Métaprogramme SusMcrop. We thank all the peasants and local facilitators who provided their valuable time to answer our questions, and especially to Pierre Rivière, Alexandre Hyacinthe for their fruitful suggestions, and to Etienne Polge for his support with the Ucinet software. We also thank the reviewers who help us to significantly improve our manuscript. Any errors remain ours.

\section{Appendix A. Supplementary data}

Supplementary data to this article can be found online at https:// doi.org/10.1016/j.ecolecon.2020.106821. 


\section{References}

Andersson, K., Ostrom, E., 2008. Analysing decentralized resource regimes from a polycentric perspective. Policy Science. 41-93.

Berkes, F., Colding, J., Folke, C., 2000. Rediscovery of traditional ecological knowledge as adaptive management. Ecol. Appl. 10 (5), 1251-1262.

Bodin, Ö., Prell, C. (Eds.), 2011. Social Networks and Natural Resources Management: Uncovering the Social Fabric of Environmental Governance. Cambridge University Press.

Bonneuil, C., Demeulenaere, É., 2007. Vers une génétique de pair à pair ? L'émergence de la sélection participative. In: Charvolin, F., Micoud, A., Nyhart, L. (Eds.), Des sciences citoyennes? La question de l'amateur dans les sciences naturalistes. L'Aube, pp. 122-147.

Bonneuil, C., Thomas, F., 2009. Gènes, pouvoirs et profits, Recherche publique et régimes de production des savoirs de Mendel aux OGM. Quae, Versailles.

Bonnin, I., Bonnieux, C., Goffaux, R., Montalent, P., Goldringer, I., 2014. Agriculture, explaining the decrease in the genetic diversity of wheat in France over the 20th century. Ecosystems and Environment. 195, 183-192.

Brac de la Perrière, R.A., 2014. Semences paysannes, plantes de demain. Charles Léopold Mayer.

Ceccarelli, S., Grando, S., 2007. Decentralized-participatory plant breeding: an example of demand driven research. Euphytica. 155, 349-360.

Chable, V., Nuijten, E., Costanzo, A., Goldringer, I., et al., 2020. Embedding cultivated diversity in Society for Agro-Ecological Transition. Sustainability. 12, 784-818.

Coomes, O., McGuire, S., Garine, E., Caillon, S. McKey, et al., 2015. Farmer seed network make a limited contribution to agriculture? Four common misconceptions. Food Policy 56, 41-50.

Cox, M., 2014. Applying a social-ecological system framework to the study of the Taos Valley irrigation system. Hum. Ecol. 42, 311-324.

Dawson, J.C., Rivière, P., Berthellot, J.-F., Mercier, F., De Kochko, P., Galic, N., Pin, S. Serpolay, E., Thomas, M., Giuliano, S., Goldringer, I., 2011. Collaborative plant breeding for organic agricultural systems in developed countries. Sustainability. 3, 1206-1223.

Demeulenaere, E., 2014. A political ontology of seeds: the transformative frictions of a farmer' movement in Europe. Journal of Global and Historical Anthropology. 69, 45-61.

Demeulenaere, É., 2018. Free our seeds! 'Strategies of farmers' movements to reappropriate seeds. In: Girard, F., Frison, C. (Eds.), The Commons, Plant Breeding and Agricultural Research. Routledge, pp. 210-225.

Demeulenaere, É., Rivière, P., Hyacinthe, A., et al., 2017. Participatory plant breeding and scale issues. On a collaboration between farmer plant breeders and field geneticists. Nature Science Societies. 25 (4), 336-346.

Epstein, G., Pittman, J., Alexander, S., Berdej, S., Dyck, T., Kreitmair, U., Rathwell, Villamayor-Tomas, K., Vogt, J., Armitage, D., 2015. Institutional fit and the sustainability of social-ecological systems. Current opinions in environmental sustainability 14, 34-40.

Folke, C., Hahn, T., Olsson, P., Norberg, J., 2005. Adaptive governance of social-ecological systems. Ann. Rev. Env. Re. 30, 441-473.

Gevers, C., van Rijswick, H., Swart, J., 2019. Peasant seeds in France: fostering a more resilient agriculture. Sustainability. 11, 3014.

Girard, F., Frison, C. (Eds.), 2018. The Commons, Plant Breeding and Agricultural Research. Routledge.

Giuliani, E., 2007. The selective nature of knowledge networks in cluster: evidence from the wine industry. J. Econ. Geogr. 7, 139-168.

Glückler, J., Lazega, E., Hammer, I. (Eds.), 2017. Knowledge and Networks. Springer.

Goldringer, I., Enjalbert, J., Rivière, P., Dawson, J., 2012. Recherche participative pour des variétés adaptées à une agriculture à faible niveau d'intrants et moins sensibles aux variations climatiques. Pour. 213 (1), 153-161.

Hess, C., Ostrom, E., 2007. Understanding Knowledge as a Commons: From Theory to Practice. MIT Press.

Janssen, M.A., Bodin, O., Anderies, J.M., Elmqvist, T., Ernstsson, H., McAllister, R.R., Olsson, P., Ryan, P., 2006. A network perspective on the resilience of social- ecological systems. Ecol. Soc. 11, 15.

Kahiluoto, H., Kaseva, J., Balek, J., et al., 2019. Decline in climate resilience of European wheat. PNAS. 116 (1), 123-128.

Koller, B., Bartha, B., Bocci, R., Carrascosa, M., Rivière, P., Andersen, R., 2018. Community Seed Banks in Europe, Report EU Project DiversiFood.

Lewrouw, F., Drochon, L., Kstler, G., De Kochko, P., Lapprand, E., Latour, F., 2014. Maisons de semences paysannes. Regards sur la gestion de la biodiversité cultivée en France. RSP.

Mazé, A., Calabuig Domenech, A., Goldringer, I., 2020. Commoning the seeds: alternative models of collective action and open innovation for recreating local knowledge commons in France. In: Working Paper.

Mc Guire, S., Sperling, L., 2013. Making seed systems more resilient to stress. Glob. Environ. Chang. 23 (3), 644-653.

Newig, J., Günther, D., Pahl-Wostl, C., 2010. Synapses in the network: learning in governance networks in the context of environmental management. Ecol. Soc. 15 (4), 24.

Osman, A., Chable, V., 2009. Inventory of initiatives on seeds of landraces in Europe. Journal of Agriculture and Environment for International Development. 103, 95-130.

Ostrom, E., 1990. Governing the Commons: The Evolution of Institutions for Collective Action. Cambridge University Press.

Ostrom, E., 2009. A general framework for analyzing sustainability of social-ecological systems. Science 325 (5939), 419-422.

Ostrom, E., 2011. Background on the institutional analysis and development framework. Policy Stud. J. 39 (1), 2-27.

Ostrom, E., Cox, M., 2010. Moving beyond panaceas: a multi-tiered diagnostic approach for social-ecological analysis. Environ. Conserv. 37 (4), 451-463.

Pahl-Wostl, C., 2009. A conceptual framework for analyzing adaptive capacity and multilevel learning processes in resource governance regimes. Glob. Environ. Chang. 19, 354-365.

Pascual, U., Narloch, U., Nordhagen, S., Drucker, A., 2011. The economics of agrobiodiversity conservation for food security under climate change. Econ. Ag. Rec. Nat 11 (1), 191-220.

Peet, R., Watts, M., 1996. Liberation Ecologies: Environment, Development, Social Movements. Routledge, London and New York.

Rivière, P., Pin, S., Galic, N., de Oliviera, Y., David, O., Dawson, J., et al., 2013. Mise en place d'une méthodologie de sélection participative sur le blé en France. Innovations Agronomiques. 32, 427-441.

Rivière, P., 2014. Méthodologie de la sélection décentralisée et participative sur le blé tendre. Thèse de doctorat en génétique. Université Paris XI, France.

Robbins, P., 2012. Political Ecology. A Critical Introduction. Wiley Blackwell.

Scott, J., 1979. The Moral Economy of the Peasant: Rebellion and Subsistence in Southeast Asia. Yale University Press.

Vanloqueren, G., Baret, Ph., 2009. How agricultural research systems shape a technological regime that develops genetic engineering but locks out agroecological innovations. Res. Policy 38 (6), 971-983.

Velten, S., Schaal, S., Leventon, J., Hanspach, J., Fischer, J., Newig, J., 2018. Rethinking biodiversity governance in European agricultural landscapes: acceptability of alternative governance scenarios. Land Use Policy 77 (84-03).

Von Hippel, E., 2005. Democratizing innovation. MIT Press.

Zimmerer, K., Haan, S. (Eds.), 2019. Agrobiodiversity: Integrating Knowledge for a Sustainable Future. MIT Press, Cambridge. 